\title{
Chapter 8 \\ Making the Case for Sustainable Urban \\ Drainage Systems as a Nature-Based Solution to Urban Flooding
}

\author{
McKenna Davis and Sandra Naumann
}

\begin{abstract}
European cities continue to experience a steady increase in the intensity and frequency of floods, largely due to high urban densities and resultant soil sealing. In the last decade, flooding as a natural hazard has produced the highest economic losses in Europe and storm water management has become a serious urban challenge.

The traditional solution to cope with excess rainwater in western cities has been piped drainage systems. These are mainly single-objective oriented designs that often no longer have the capacity to keep pace with on-going urbanisation and the impacts of climate change, and frequently involve high construction, maintenance, and repair costs. While such approaches have certainly reduced the damages incurred from flooding events during the past two centuries and are arguably still necessary for extreme flood events in the future, alternative approaches that accomplish these aims and offer additional benefits are progressively being pursued. Given these conditions, one increasingly utilised solution for managing flood risk by dealing with water at the source is sustainable urban drainage systems (SUDS). Other terms which also aim to minimise potential impacts on the neighbouring environment, people and development include inter alia BMP (Best Management Practices); LID (Low Impact Development); WSUD (Water Sensitive Urban Design) (see: Fletcher et al., Urban Water J 12(7):525-542, 2015 for a complete taxonomy).

SUDS as a promising nature-based solution are the focus of this chapter, utilizing a range of case studies and evidence from across Europe to underline the arguments presented. Besides reducing the negative effects of urban flooding and interlinked water pollution, the many supplementary benefits and potential cost-effectiveness of SUDS as compared to grey infrastructure solutions are also presented. In addition to highlighting relative advantages, the chapter also outlines current challenges facing a wider uptake of SUDS and presents approaches to help overcome existing social and political barriers.

The promise of ongoing research, targeted collaboration and partnerships and an ever-growing evidence base on the effectiveness and associated costs and benefits of SUDS serve as strong tools to improve the confidence and competence associated
\end{abstract}

M. Davis $(\bowtie) \cdot S$. Naumann

Ecologic Institute, Berlin, Germany

e-mail: mckenna.davis@ecologic.eu; sandra.naumann@ecologic.eu 
with their design and implementation. Such data will help to refute existing public and political hesitation as compares to traditional grey infrastructure approaches to water management. However, the significant potential for more widespread uptake remains largely untapped. Further targeted actions are necessary for increasing the acceptance and application of this nature-based solution and realizing its full potential.

Keywords SUDS • Sustainable urban drainage system • nature based solution • flood management $\bullet$ Europe $\bullet$ cost-benefit analysis

\subsection{Introduction}

European cities continue to experience an increase in the intensity and frequency of floods, with further escalations projected as a result of climate change and rapid urbanization (Santato et al. 2013). Particularly in urban areas, the management and drainage of storm water presents a serious challenge. The high urban density within cities and resultant soil sealing has lead to a reduction in the potential of water infiltration in the ground, which increases run-off water and flood risk (EEA 2012).

The traditional solution to these challenges in western cities has been 'grey' infrastructure - such as piped drainage systems - which are mainly single-objective oriented designs to cope with rainwater within the urban landscape. However, these drainage infrastructures often no longer have the capacity to keep pace with on-going urbanisation and the increasing rate of storm water due to climate change and soil sealing, and can lead to increased run-off and a higher risk of urban flooding (EEA 2012; PeralesMomparler et al. 2016; Zhou 2014). Additional indirect consequences are an insufficient discharge of excess water to the regional water system, and an increase of pollutants in the water caused by run-off (e.g., oil, organic matter and toxic metals), leading to increases in algal blooms, harm to wildlife and reductions in amenity value (Sharma 2008). Furthermore, managing storm water runoff through grey infrastructure approaches typically entails high construction, maintenance, and repair costs (Hair et al. 2014).

While 'grey' approaches have certainly reduced the damages incurred from flooding events during the past two centuries and are arguably still necessary for extreme flood events in the future, alternative approaches that accomplish these aims while offering additional benefits are progressively being pursued (Jones and Macdonald 2007; Perales-Momparler et al. 2016). Sustainable urban drainage systems (SUDS), ${ }^{1}$ which are outlined in detail in the subsequent section, represent one such promising alternative flood risk management tool in the transition towards achieving regenerative urban built environments.

SUDS as a type of nature-based solution are the focus of this chapter, particularly concentrating on the existing evidence base regarding the potential for delivering a wide range of benefits as compares to purely grey solutions. The chapter also highlights challenges that are currently limiting more widespread uptake of these greener approaches

\footnotetext{
${ }^{1}$ Other terms are used elsewhere: inter alia BMP (Best management practices); LID (Low Impact Development); WSUD (Water Sensitive Urban Design) (see: Fletcher et al. 2015 for a complete taxonomy)
} 
and identifies potential solutions and needs to improve the confidence and competence associated with designing and implementing SUDS. The research results presented were gathered by the authors via an analysis of literature, expert interviews and EU level stakeholder workshops in the context of the EU research project RECREATE. ${ }^{2}$

\subsection{Using Green Alongside Grey as an Alternative Approach to Flood Protection}

Instead of focusing on 'end-of-pipe' or 'at the point of the problem' solutions as is the case with many purely 'grey' infrastructure solutions, sustainable urban drainage systems aim to slow down and reduce the quantity of surface water runoff in an area in order to minimize downstream flood risk and reduce the risk of resultant diffuse pollution to urban water bodies (Rose and Lamond 2013; Woods Ballard et al. 2015; Zhou 2014). As a nature-based solution, SUDS achieves these aims by utilizing a mix of natural processes ${ }^{3}$ and green/grey components ${ }^{4}$ to harvest, infiltrate, slow, store, convey and treat runoff onsite; examples include the following (from Woods Ballard et al. 2015):

- Rainwater harvesting systems - collect and store rainwater from roofs and other paved surfaces (such as car parks) for re-use

- Green roofs - involve constructing a soil layer on a roof to create a living surface that reduces surface runoff

- Permeable pavements - act as a hard surface for walking or driving, while enabling rainwater to infiltrate to the soil or underground storage

- Bioretention systems (such as rain gardens) - collect runoff in a temporary surface pond before it filters through vegetation and underlying soils

- Trees - capture rainwater while also providing evapotranspiration, biodiversity and shade

- Swales, detention basins, retention ponds and wetlands - slow the flow of water, store and treat runoff while draining it through the site and encouraging biodiversity

- Soakways and infiltration basins - promote infiltration as an effective means of controlling runoff and supporting groundwater recharge

These solutions are diverse in nature and can take many different forms both above and below ground, depending on the state and characteristics of the drainage system in place and the components utilized (State of Green 2015). Table 8.1 provides illustrative examples of different forms of SUDS which have been implemented across Europe.

SUDS can be implemented either as a new development or as a retrofit of existing structures. Regardless of the type, the central objective of all SUDS is to fully

\footnotetext{
${ }^{2}$ REsearch network for forward looking activities and assessment of research and innovation prospects in the fields of Climate, Resource Efficiency and raw mATErials (RECREATE): URL: http:// www.recreate-net.eu/

${ }^{3}$ These could include, for example, evaporation, infiltration, re-use and plant transpiration.

${ }^{4}$ Including, for example, permeable surfaces, filter strips, filter and infiltration trenches, green roofs, swales, detention basins, underground storage, wetlands and/or retention ponds.
} 
Table 8.1 European examples of SUDS and their components

Lamb Drove, Cambourne, United Kingdoma
A demonstrative SUDS scheme was implemented in a
residential development area in Cambourne to highlight
innovative sustainable water management techniques
within new developments. A variety of SUDS elements
were implemented across the one hectare site, including
permeable paving, green roofs, swales, filter strips,
wetlands, and a retention pond. Results indicate e.g.,
improvements in biodiversity and water quality leaving the
site, increased amenity and social values and cost savings
to residents by avoiding stormwater disposal charges.
Furthermore, the project concludes that many aspects of
SUDS can be installed and maintained at lower costs than
more traditional forms of drainage.
Valencia, Spain
Within the framework of the EU-funded AQUAVAL
project, SUDS (infiltration basin, green roof, swales, etc.)
were implemented in six sites across the Valencian region.
The measures came as a response to shortcomings of the
existing urban sewer system, which insufficiently abated
frequent rainfall and caused pluvial flooding and the
discharge of combined sewage into the receiving water
courses. Monitoring results showed that SUDS performed
well hydraulically under Mediterranean climate conditions
and improve the water quality.
Monnikenhuizen, Arnhem, Netherlands
The Monnikenhuizen study site was selected for its unique
and challenging topographic and contextual conditions for
utilizing SUDS, as it is located on a hill and surrounded by
forests and contains 204 residences. On a small scale,
greenroofs and permeable parking lots were created; on a
larger scale, water from the road is led via gutters to an
infiltration and storage pond.

Text/photo sources: Pledger n.d. (UK); Perales-Momparler et al. 2016/ Perales-Momparler 2012 (Spain); 2BG 2008 (Netherlands)

aThe project was part of a European funded programme (FLOWS), which featured 40 projects throughout Germany, the Netherlands, Norway, Sweden and the UK

exploit the opportunities and benefits that can be obtained from surface water management (Woods Ballard et al. 2015).

\subsection{Making the Investment Case for SUDS}

In the past decade, more than 165 major floods evoking significant economic damages have taken place across Europe, making flooding (including from rivers, the sea and direct rainfall) the most widespread natural hazard on the continent in terms of economic loss (CRED 2009). In 2002, for example, flooding events occurred in six EU Member States and created infrastructure damages amounting to more than $€ 18.7$ 
billion (Santato et al. 2013). These damages highlight the shortcomings of piped systems as a stand-alone solution to address flooding, and imply the vast potential for replacing and complementing these systems with alternative nature-based approaches.

By integrating natural elements into their design, SUDS can serve to not only address the primary objective of improved water quality and quantity management, but can also offer a wide range of additional benefits which are supplementary to those of purely "grey" solutions (Charlesworth et al. 2016). SUDS can, for example, improve public health, create amenity values in the targeted areas, provide recreational opportunities, support the local ecology and biodiversity, and capture carbon (e.g., Burns et al. 2012; Charlesworth 2010; Norton et al. 2015; Novotny et al. 2010). Table 8.2 presents a more comprehensive overview of these and other potential benefits.

Table 8.2 SUDS benefit types, descriptions and provisioning details

\begin{tabular}{|c|c|c|}
\hline Benefit category & Description & $\begin{array}{l}\text { Aspects of the SUDS design that } \\
\text { provide the benefit }\end{array}$ \\
\hline Air quality & $\begin{array}{l}\text { Reduced damage to health } \\
\text { from improved air quality }\end{array}$ & $\begin{array}{l}\text { Air particulate filtering via vegetation } \\
\text { (e.g., trees and green roofs) }\end{array}$ \\
\hline $\begin{array}{l}\text { Air and building } \\
\text { temperature }\end{array}$ & $\begin{array}{l}\text { Cooling or insulation; thermal } \\
\text { comfort and energy savings }\end{array}$ & Green and blue spaces, green roofs \\
\hline $\begin{array}{l}\text { Biodiversity and } \\
\text { ecology }\end{array}$ & Sites of ecological value & $\begin{array}{l}\text { Habitat creation and enhancement, } \\
\text { connecting habitats }\end{array}$ \\
\hline $\begin{array}{l}\text { Carbon reduction and } \\
\text { sequestration }\end{array}$ & $\begin{array}{l}\text { Reduced energy/water use and } \\
\text { planting }\end{array}$ & $\begin{array}{l}\text { Low energy needs (materials, } \\
\text { construction and maintenance); } \\
\text { sequestration (e.g., trees and wetlands) }\end{array}$ \\
\hline $\begin{array}{l}\text { Climate change } \\
\text { adaptation }\end{array}$ & $\begin{array}{l}\text { Ability to make incremental } \\
\text { changes to systems }\end{array}$ & $\begin{array}{l}\text { Designing for exceedance, adaptability } \\
\text { of scheme }\end{array}$ \\
\hline $\begin{array}{l}\text { Community cohesion } \\
\text { and crime reduction }\end{array}$ & $\begin{array}{l}\text { Crimes against property or } \\
\text { people }\end{array}$ & $\begin{array}{l}\text { See visual character, economic growth/ } \\
\text { inward investment and education }\end{array}$ \\
\hline $\begin{array}{l}\text { Economic growth and } \\
\text { inward investment }\end{array}$ & $\begin{array}{l}\text { Business, jobs, productivity, } \\
\text { tourism, property prices }\end{array}$ & $\begin{array}{l}\text { See visual character, recreation and air } \\
\text { and building temperature }\end{array}$ \\
\hline $\begin{array}{l}\text { Education } \\
\text { opportunities }\end{array}$ & $\begin{array}{l}\text { Enhanced access to and } \\
\text { existence of educational } \\
\text { possibilities }\end{array}$ & $\begin{array}{l}\text { Community engagement (before and } \\
\text { after construction), information boards, } \\
\text { education programmes, play features }\end{array}$ \\
\hline Flood risk reduction & Damage to property and people & Peak flow attenuation, volume control \\
\hline $\begin{array}{l}\text { Groundwater and soil } \\
\text { moisture recharge }\end{array}$ & $\begin{array}{l}\text { Improved water availability or } \\
\text { quantity }\end{array}$ & $\begin{array}{l}\text { Interception, infiltration, runoff } \\
\text { treatment }\end{array}$ \\
\hline $\begin{array}{l}\text { Health and } \\
\text { well-being }\end{array}$ & $\begin{array}{l}\text { Physical, emotional and } \\
\text { mental health benefits }\end{array}$ & $\begin{array}{l}\text { See air quality and building } \\
\text { temperature, recreation, crime } \\
\text { reduction, reduced flood risk }\end{array}$ \\
\hline Recreation & $\begin{array}{l}\text { Involvement in specific } \\
\text { recreational activities }\end{array}$ & $\begin{array}{l}\text { Green and blue spaces and play } \\
\text { features }\end{array}$ \\
\hline $\begin{array}{l}\text { Security of water } \\
\text { supply }\end{array}$ & $\begin{array}{l}\text { Reduced flows and reduced } \\
\text { pollution }\end{array}$ & $\begin{array}{l}\text { Rainwater harvesting; also see } \\
\text { groundwater and soil moisture recharge }\end{array}$ \\
\hline $\begin{array}{l}\text { Sewerage systems } \\
\text { and sewage treatment }\end{array}$ & $\begin{array}{l}\text { Reduced flows and volume to } \\
\text { treat in combined systems }\end{array}$ & $\begin{array}{l}\text { Interception and further runoff volume } \\
\text { reduction }\end{array}$ \\
\hline Visual character & $\begin{array}{l}\text { Attractiveness and desirability } \\
\text { of area }\end{array}$ & $\begin{array}{l}\text { Visual enhancement (as part of surface } \\
\text { SUDS) }\end{array}$ \\
\hline Water quality & $\begin{array}{l}\text { Surface water quality } \\
\text { improvements }\end{array}$ & $\begin{array}{l}\text { Pollution prevention strategies, } \\
\text { interception, runoff treatment }\end{array}$ \\
\hline
\end{tabular}

Source: Ashley et al. 2015 and Woods Ballard et al. 2015 
While the extent and nature of SUDS benefits are site-specific and depend on the attributes of the build or retrofit, several resources exist to support the quantification and monetisation of benefits offered in a given context. Such data serves to support decision-making processes and ultimately mainstream SUDS by providing comparative information on purely "grey" versus "green" or "mixed" solutions. The BeST tool ('Benefits of SUDS Tool'), for example, was developed within the project 'Demonstrating the multiple benefits of SUDS' to enable practitioners to evaluate the wider benefits of SUDS in cases where surface water management is a key driver ${ }^{5}$ (Digman et al. 2015). The UK's SUDS Manual (see Woods Ballard et al. 2015) also outlines key concepts in estimating the costs and benefits of SUDS schemes and provides tools and further resources for assessments and comparisons to purely 'grey' infrastructure. A case study from this manual is provided in Box 8.1, illustrating the potential benefits arising from a SUDS scheme versus a conventional drainage solution.

\section{Box 8.1 Application of the BeST Tool to Compare the Benefits of Different Drainage Options: Roundhay Park, Leeds (UK)}

Yorkshire Water utilized the BeST tool in order to compare the potential of different options to reduce combined sewer overflow (CSO) spills in Roundhay Park in Leeds (UK). As an additional decision-making criterion, the benefits that could be delivered by each option were also assessed (see Table 8.3). The four options considered used a range of conventional drainage and/or SUDS approaches, namely:

- Option 1: a conventional solution to store water in tanks at CSOs to limit the volume spilling

- Option 2: a conventional option also solving predicted flooding in the catchment, giving similar hydraulic performance in the combined sewer network as in options 3 and 4

- Option 3: a SUDS approach in public areas to disconnect surface water from the combined system and pass it through the conveyance and storage SUDS

- Option 4: as option 3, with measures added in residential private locations

Ultimately, Option 1 lowered the CSO spills but failed to generate other benefits. Option 2 would offer similar drainage benefits to the sewer network as Options 3 and 4, but created less benefits due to underground infrastructure and was less resilient to climate change. As Options 3 and 4 created wider additional benefits to the community and environment with similar costs and benefits, the final selection was to pursue the public SUDS scheme as it had the best net present value (Option 3). The associated costs and benefits are illustrated in Fig. 8.1.

\footnotetext{
${ }^{5}$ See http://www.susdrain.org/resources/best.html
} 


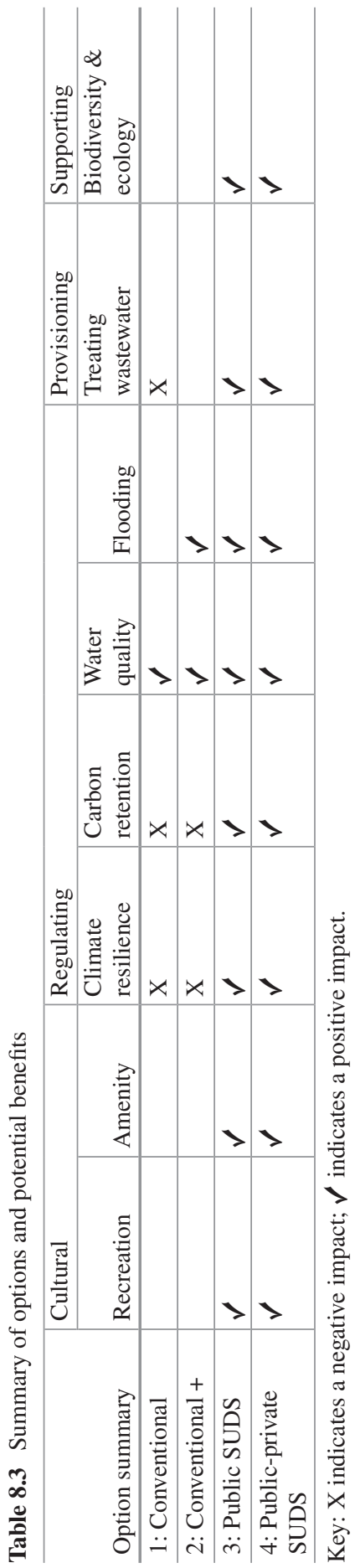




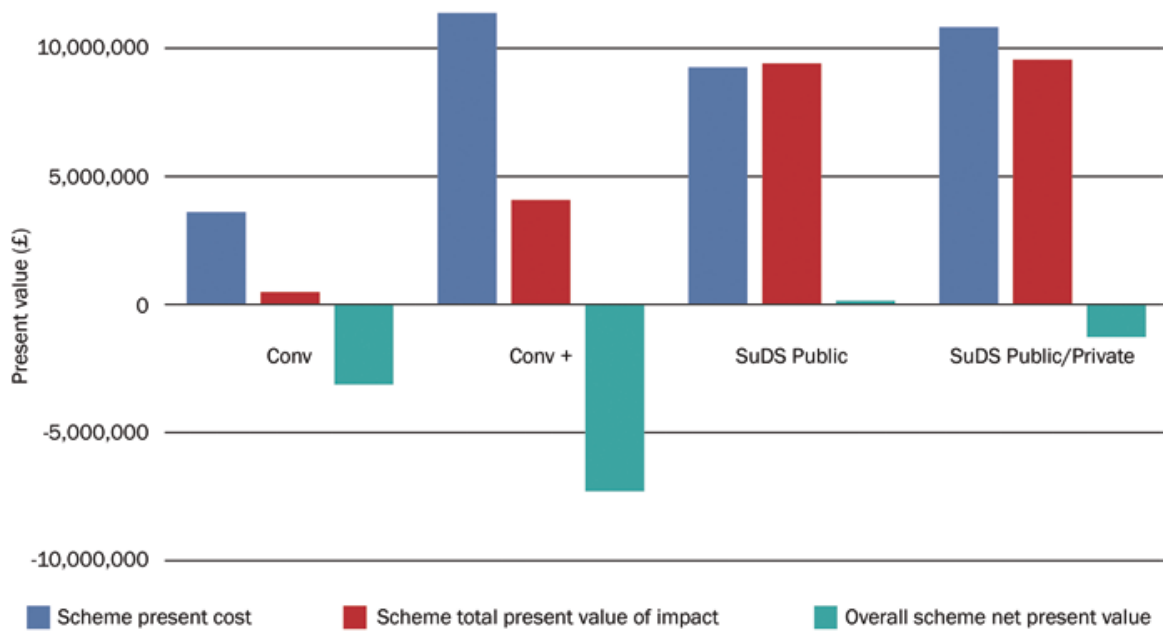

Fig. 8.1 Comparison of options: costs vs benefits (Source: Woods Ballard et al. 2015)

As shown in the above example, research also indicates that where SUDS "are designed to make efficient use of the space available, they can often cost less to implement than underground piped systems" (Woods Ballard et al. 2015: 8) as well as less to maintain. Further comparative studies on the capital (and sometimes the maintenance) costs and benefits of traditional drainage and SUDS have been conducted by Defra as part of their work on the Flood and Water Management Act (see e.g., Defra 2011, 2015). SUDS were found to offer cost savings of between approximately $10 \%$ and $85 \%$ as compared to traditional drainage approaches, with variations due to site and installation differences. Significant cost savings can be incurred inter alia due to the storage provided within landscape features and resultant reductions in the need for expensive boxed storage and creating low maintenance and monitoring costs (Defra 2011).

It should be emphasized, however, that further long-term research is necessary on the delivery and valuation of benefits as compares to piped solutions and particularly on the aspect of cost-effectiveness in different scenarios, contexts and combinations. Additional data is needed here to improve the targeted deployment of particular aspects and combinations of these technologies and design an optimal framework integrating technical, social, environmental, economic, legal and institutional aspects (Zhou 2014). These gaps as well as additional challenges to be addressed to foster a wider uptake of SUDS are outlined in the subsequent section. 


\subsection{Fostering a Wider Uptake and Implementation of SUDS}

Despite the strong drivers and manifold benefits, SUDS have not been exploited or implemented to their full potential. Uncertainty about long-term maintenance, performance and (cost-) effectiveness both independently and as compared to purely grey infrastructure solutions serve as limitations to wider uptake. These informational limitations are particularly challenging to address as the restricted implementation in turn prohibits new data and evidence from being generated. Furthermore, the data and quantification of these aspects that do already exist are not widely known by the necessary actors, and therefore are commonly not considered alongside "grey" infrastructure. Given that SUDS are a rapidly evolving technology and are very site-specific in nature, another complication is that the levels of effectiveness, fulfilment of associated land requirements, costs and benefits vary greatly from case to case (Green Nylen and Kiparsky 2015). Technical, institutional/political, financial and social barriers relating to the above considerations are further impediments. Key challenges include obtaining the revenue to undertake maintenance, the potential land take and physical requirements involved in new developments, and the role of regulation (Ashley et al. 2015).

Strategies, regulatory frameworks and national level targets which exist to support SUDS implementation are currently scattered, with the majority of information on implementation and case studies limited to only a few countries (e.g. the UK, United States and Australia). For example, as a frontrunner in the field, the UK has SUDS legislation in place as part of the National Planning Policy Framework, which requires local authorities to include SUDS on new developments of 10 or more homes and all major new commercial and mixed use developments, unless demonstrated to be inappropriate. In consultation with the Lead Local Flood Authority, the Local Planning Authority then needs to approve drainage schemes (in line with nonstatutory standards ${ }^{6}$ ). Also in the UK, CIRIA $^{7}$ has published an extensive guidance manual addressing the planning, design, construction and maintenance of SUDS as well as tools for maximising amenity and biodiversity benefits alongside flood risk reduction and water quality improvement (see Woods Ballard et al. 2015).

However, even in the limited contexts where SUDS are comparatively more widely implemented, such as in the UK, the challenge remains to overcome silo thinking. SUDS are often raised as a possible approach only when targeting surface water and flooding issues, despite their potential to also address water quality challenges and deliver wider benefits in parallel. This stems in part from dispersed responsibilities amongst agencies for these topics as well as a problematic disconnect between research/development activities and implementation in many cases, leading to limited knowledge of available data and potential scepticism regarding its validity.

\footnotetext{
${ }^{6}$ See https://www.gov.uk/government/uploads/system/uploads/attachment_data/file/415773/sustainable-drainage-technical-standards.pdf

${ }^{7}$ CIRIA is a neutral, independent and not-for-profit British construction industry research and information association (see http://www.ciria.org/).
} 


\subsection{Addressing Silos and Informational Gaps}

In order to address the outlined issues and improve the confidence and competence associated with designing and implementing SUDS, further coordinated research and targeted implementation initiatives are crucial. In addition to monitoring the performance, implementation and effectiveness of SUDS in cities, there is a need to disseminate this information highlighting the proven utility of SUDS in a targeted format to key stakeholder groups and decision makers. Such evidence could help appease existing hesitation and scepticism in choosing such a nature-based solution over the traditional grey alternative by providing evidence to questions of performance uncertainty. By providing a wealth of good practice experiences and accompanying monitoring data, a gradual change in stakeholder perception could be facilitated and therewith increased uptake and ecologic, socio-economic and monetary gains (Castro-Fresno et al. 2013; Perales-Momparler et al. 2016). Other research needs are on adequate institutional arrangements, human resource requirements, and performance indicators for urban drainage, which include the range of technical, economical, social and environmental aspects of SUDS (Ashley et al. 2013) as well as the improved quantification of benefits in order to capitalize on the potential future market.

Several research projects are aiming to fill these existing gaps by utilizing sound science to develop tools and guidance materials and implement demonstrative or pilot projects. The Danish 2BG "Black, Blue \& Green" project, for example, commits to integrated infrastructure planning for sustainable urban water systems (DTU 2011), Ireland has several regional drainage assessment projects on integrated constructed wetlands, and the Swedish "Sustainable Urban Water Management" project focuses on protecting valuable water resources in urban areas. ${ }^{8}$ The EU LIFE+ funded AQUAVAL project ("The efficient management of rain water in urban environments") was highlighted earlier. It aims to find, implement and promote innovative solutions to decrease the impacts of developments on quantity and quality of urban runoff in Valencia, Spain, and implements SUDS as an important step in a paradigm shift (AQUAVAL 2010). Thames Water in the UK has also launched the 'Twenty 4 Twenty' initiative, a ca. 26 million Euro campaign aiming to transform at least 20 acres of grey impermeable concrete into sustainable drainage projects by 2020 (Thames Water 2015). Finally, a newly published study by Allitt et al. (2015) identifies the wider benefits of SUDS and provides guidance to water and sewerage companies on approaches to maximise the potential for benefits to be realised. The UK's SUDS Manual (see Woods Ballard et al. 2015) also provides numerous good practice examples, tools and approaches for successful SUDS design, implementation and maintenance.

Due to the inherent need for cross-sectoral cooperation in designing, implementing and maintaining SUDS, efforts could also be placed on involving local communities in decision-making processes, instead of only presenting these actors

\footnotetext{
${ }^{8}$ See http://www.urbanwater.se/en
} 
with end results. This is underlined by Hair et al. (2014) and Ashley et al. (2013), who suggest to encourage stakeholder involvement and education at all levels of decision-making processes to improve transparency and foster trust and therewith increase acceptance and engagement by addressing citizen, business and political concerns (see Box 8.2). In this context, also employing collaborative governance approaches as suggested by Kabisch et al. (2016) to foster collaboration between decision makers and citizens, businesses and civil society connecting demands for action with responsible actors or partnerships for action could be a promising instrument to reduce barriers for adopting and implementing SUDS. Investments in social-cultural research and the development of cross-disciplinary language could be valuable venues by which to increase public acceptability and support, particularly given that many of the decisions on SUDS retrofits are the responsibility of property owners.

\section{Box 8.2 Herne Hill and Dulwich Flood Alleviation Scheme: A Model for Citizen Engagement and Public-Private Cooperation in SUDS Implementation}

Several linked SUDS were installed in a public and two private parks in Southwark, London (UK) in order to stop the recurrent flooding of homes and businesses along the River Effra. The award-winning scheme involved a public-private partnership and shared costs between Southwark Council and Thames Water, with support from the UK Environment Agency (EA). The scheme was designed and delivered in close collaboration and represents one of the first multi-agency SUDS schemes to be implemented in London. Of the total costs, the Council contributed 5\%, Thames Water 54\% and the EA mediated flood defence grant $41 \%$ in aid. Furthermore, Thames Water have provided funding to the Council for long-term maintenance, which is an important aspect for continued delivery given the 100-year design life of the project.

As a result of the project, 447 properties are at reduced risk of surface water flooding and over 80 properties have a reduced risk of sewer flooding. In addition to the direct economic benefits (valued at ca. 12 million pounds), the SUDS scheme has been praised for the extensive stakeholder involvement with the local community interest groups, businesses and residents. The invested outreach efforts were central to gaining support for the scheme and ensuring the continued delivery of amenity and environmental benefits. After receiving the ICE Engineering Award 2015, the EU Project Excellency Award 2015 (for partnership) and being shortlisted for the British Construction Industry Awards 2015, the SUDS project serves as a strong example for future approaches to reduceing surface water flooding risk in urban regions.

Source: Woods Ballard et al. (2015) 
Some initiatives have already been set in motion that support a more integrated approach or novel partnerships. For example, the Cooperative Research Centre for Water Sensitive Cities in Australia joins over 70 inter-disciplinary partners together to deliver sustainable water strategies that facilitate a city-wide transformation into a more liveable and resilient environment (CRC 2016). Further innovative approaches encouraging the implementation of SUDS and relevant green infrastructure elements by citizens were developed by the city of Hamburg, Germany. The RISA-project, ${ }^{9}$ a cooperation between the city council and a private water company, aims to identify sustainable responses to avoid flooding of basements, streets and properties as well as water pollution from combined sewer overflow and urban runoff. It also seeks to integrate water management measures into urban and regional planning and develop a plan and guidance for rainwater management in the future. In addition, the city of Hamburg launched a green roof strategy ${ }^{10}$ in 2016 providing financial support to citizens to install green roofs. In result not only water retention capacity in the city can be increased, but fees for sewage water and rainwater can also be reduced.

Efforts in the UK are also frontline in this regard, recognizing the value of partnerships to secure multiple sources of capital funding and share responsibility for long-term costs. The 'Herne Hill and Dulwich flood alleviation scheme', for instance, is an award-winning example of a successful public-private partnership for delivering SUDS (Southwark Council 2016; see Box 8.2). The UK Water Industry Research (UKWIR) ${ }^{11}$ also finances proposals for collaborative research with joint funding and leverage, welcoming new partnerships and innovative associations for common research on SUDS.

\subsection{Ways Forward for Increased SUDS Deployment}

As urban populations grow alongside projected threats from climate change, demand is mounting for resilient future cities that can both protect the population from climatic events and offer further benefits in parallel. This chapter has thus presented a nature-based alternative to the historically pursued purely piped systems for addressing urban flooding which has the potential to support sustainable urban developments and provide recreational, aesthetic, environmental and socio-economic benefits. SUDS offer significant potential in this regard as evidence indicates a high potential for being sustainable, cost-effective approaches which can complement pure grey infrastructure, and can be applied within new developments or used to retrofit existing systems.

While a range of challenges have been outlined which threaten the wider uptake of SUDS, the promise of ongoing research, targeted collaborative and dissemination

\footnotetext{
${ }^{9} \mathrm{http}: / /$ www.risa-hamburg.de/english.html

${ }^{10} \mathrm{http} / / / \mathrm{www} \cdot h a m b u r g . d e / g r u e n d a c h / 4364756 /$ gruendachfoerderung/

${ }^{11}$ See https://www.ukwir.org/
} 
initiatives and an ever-growing evidence base of the effectiveness and associated costs/benefits of SUDS serve as strong countermeasures. Here, it is important to make lessons learned and data gathered from existing cases more widely available. New pilot or demonstration projects should also be promoted and invested in which are collaborative in nature and strengthen the links between researchers, practitioners and relevant community stakeholders. Finally, the targeted involvement of groups that are perhaps not traditionally interested in drainage matters, such as those in the health or transport sectors, and encouragement of exchanges between companies having implemented SUDS and those pursuing purely grey solutions can also benefit the mainstreaming of SUDS.

These efforts can in turn strengthen the 'business case' for SUDS by instilling more confidence in and drawing attention to their wider benefits produced, low comparative associated costs, and climate change compatible nature. Such evidence will help to refute public and political hesitation as compares to traditional grey infrastructure approaches to water management. Highlighting the delivery of the multiple benefits produced in addition to flood protection which traditional engineered flood protection schemes cannot deliver is a central element. New businessmodels for public-private partnerships are a further aspect of this process, combining blue/green spaces, human well-being, water management and climate change adaptation interests (see Box 8.2 for an example). Establishing such 'business case' arguments will serve as the foundation for increased investment, public and political support and ultimately SUDS deployment.

Once confidence exists that SUDS are effective and affordable as a nature-based solution technology, governments can increasingly support wider implementation. Means to do so include establishing an adequate legal framework that builds upon the evidence gathered and - alongside financial agreements/investment banks helping to bridge the gap between short-term thinking and long-term investments via intentional regulatory design. At the EU level and in other industrialized countries, potential actions could experiment with and adjust institutional settings, considering alternative local capacities and site-specific cultural aspects. By requiring use of the technology and establishing duties for adoption and maintenance, governments can ensure the implementation of SUDS and facilitate a transition to becoming a 'business as usual' option and highlight the importance of such an approach as a national priority. More specifically, national regulators can use their authority to more actively accelerate and improve SUDS development by adopting standardized monitoring and reporting protocols and guidance and by incentivising and highlighting the importance of voluntary monitoring.

A strong evidence base exists which demonstrates the effectiveness of SUDS and highlights their promise as a sustainable solution to reduce urban flooding. Yet, the significant potential for more widespread uptake remains largely untapped. Further targeted actions are necessary for increasing the acceptance and application of this nature-based solution and realizing its full potential. 


\section{References}

2BG (2008) Sustainable urban drainage systems -8 case studies from the Netherlands. Working Paper, University of Copenhagen \& Technical University of Denmark, Black, Blue and Green $\mathrm{PhD}$ course, pp 20-22

Allitt R, Tanzir C, Massie A, Sherrington CA (2015) Realising the wider benefits of sustainable drainage. ISBN: $184057769 \mathrm{X}$

AQUAVAL (2010) Project Objectives. Accessed on 30 Sept 2016 at http://www.aquavalproject.eu/ adaptingContenidos/muestrausuario.asp?accADesplegar=113\&IdNodo=14

Ashley R, Shaffer P, Walker L (2013) Sustainable drainage systems: research roadmap. On behalf of UKWIR. Final report

Ashley RM, Walker L, D’Arcy B, Wilson S, Illman S, Shaffer P, Woods-Ballard B, Chatfield P (2015) UK sustainable drainage systems: past, present and future. Civil Engineering Proceedings of the Institution of Civil Engineers. ICE Publishing

Burns et al (2012) Hydrologic shortcomings of conventional urban stormwater management and opportunities for reform. Landsc Urban Plan 105:230-240

Castro-Fresno et al (2013) Sustainable drainage practicies in Spain, specially focused on pervious pavements. Water 5:67-93

Charlesworth (2010) A review of the adaptation and mitigation of global climate change using sustainable drainage in cities. J Water Clim Change 1(3):165-180

Charlesworth et al (2016) Renewable energy combined with sustainable drainage: ground source heat and pervious paving. Renewable and Sustainable Energy Reviews, Articile in Press, pp 1-8

CRC (2016) Global partnerships. Available online at: https://watersensitivecities.org.au/collaborate/global-partnerships/

CRED (2009) Disaster data: a balanced perspective. CRED Crunch, Centre for Research on the Epidemiology of Disasters (CRED), Issue No. 17, Brussels

Defra (2011) Comparative costings for surface water sewers and SUDS. Cases: Daniels Cross, Newport, Shropshire; Red Hill C.of E. Primary School, Worcester; Caledonian Road Housing, Islington, London; Railfreight Terminal, Telford, Shropshire; Marlborough Road, Telford, Shropshire; URL: http://www.susdrain.org/delivering-suds/using-suds/the-costs-and-benefitsof-suds/comparison-of-costs-and-benefits.html

Defra (2015) Cost estimation for SUDS - summary of evidence. Report -SC080039/R9

Digman CJ, Horton B, Ashley RM et al (2015) Getting the BeST from SUDS. In: Proceedings of the Chartered Institution of water and environmental management urban drainage group spring conference, Birmingham, UK

DTU (2011). 2BG: black, blue and green - Integrated infrastructure planning as key to sustainable urban water systems. Accessed 30 Sept 2016 at http://orbit.dtu.dk/en/projects/2bg-black-blueand-green--integrated-infrastructure-planning-as-key-to-sustainable-urban-watersystems(36195120-7c7e-4efe-bc00-78d01bb7a678).html

EEA (2012) Urban adaptation to climate change in Europe - challenges and opportunities for cities together with supportive national and European policies

Fletcher T, Shuster W, Hunt WF, Ashley R, Butler D, Arthur S, Trowsdale S, Barraud S, SemadeniDavies A, Bertrand-Krajewski J, Mikkelsen PS, Rivard G, Uhl M, Dagenais D, Viklander M (2015) SUDS, LID, BMPs, WSUD and more - the evolution and application of terminology surrounding urban drainage. Urban Water J 12(7):525-542

Green Nylen N, Kiparsky M (2015) Accelerating cost-effective green stormwater infrastructure: learning from local implementation. Center for Law, Energy \& the Environment, U.C. Bekeley School of Law. http://law.berkeley.edu/cost-effective-GSI.htm

Hair L, Clements J, Pratt J (2014) Insights on the economics of green infrastructure: a case study approach. Water Economics Federation, WEFTEC 2014, pp 5556-5585

Jones P, Macdonald N (2007) Making space for unruly water: sustainable drainage systems and the disciplining of surface runoff. Geoforum 38:534-544

Kabisch N, Frantzeskaki N, Pauleit S, Naumann S, Davis M et al (2016) Nature-based solutions to climate change mitigation and adaptation in urban areas -perspectives on indicators, knowledge gaps, barriers and opportunities for action. Ecol Soc 21(2):39 
Norton et al (2015) Planning for cooler cities: a framework to prioritise green infrastructure to mitigate high temperatures in urban landscapes. Landsc Urban Plan 135:127-138

Novotny et al (2010) Water centric sustainable communities: planning, retrofitting, and building the next Urban environment. Wiley, New Jersey. ISBN 978-0-470-47608-6

Perales-Momparler S (2012) Demonstration SUDS in the Mediterranean region of Valencia. SUDSnet International Conference. 5th September 2012, Conventry University, UK. Available for download at: http://sudsnet.abertay.ac.uk/presentations/National\%20Conf\%202012/ Session7_AQUAVALDemonstrationSUDSInTheMediterraneanRegionOfValencia_Perales.pdf

Perales-Momparler S, Andrés-Doménech I, Hernández-Crespo C, Vallés-Morán F, Martín M et al (2016) The role of monitoring sustainable drainage systems for promoting transition towards regenerative urban built environments: a case study in the Valencian region, Spain. J Clean Prod, Article in Press, pp 1-12

Pledger S (n.d.) Lamb Drove, Residential SUDS scheme, Cambourne. Accessed at http://www. susdrain.org/case-studies/case_studies/lamb_drove_residential_suds_scheme_cambourne. html, on 18 Sept 2016

Rose C, Lamond J (2013) Performance of sustainable drainage for urban flood control, lessons from Europe and Asia. In: International conference on flood resilience, experiences in Asia and Europe, Exeter, United Kingdom, 5-7 Sept 2013

Santato S, Bender S, Schaller M (2013)The European floods directive and opportunities offered by land use planning. CSC Report 12, Climate Service Center, Germany. Available for download at: http://www.climate-service-center.de/imperia/md/content/csc/csc-report_12.pdf

Sharma D (2008). Sustainable drainage system (SUDS) for stormwater management: a technological and policy intervention to combat diffuse pollution. 11th International conference on urban drainage, Edinburgh, Scotland, UK, 2008. Available for download at: http://web.sbe.hw.ac.uk/ staffprofiles/bdgsa/11th_International_Conference_on_Urban_Drainage_CD/ICUD08/ pdfs/753.pdf

Southwark Council (2016) Herne Hill and Dulwich Flood Alleviation Scheme. Accessed 30 Sept 2016 at http://www.southwark.gov.uk/info/200448/flood_risk_management/3889/herne_hill_ and_dulwich_flood_alleviation_scheme

State of Green (2015) Sustainable urban drainage systems: using rainwater as a resource to create resilient and liveable cities. Available online at: https://stateofgreen.com/files/download/8247

Thames Water (2015) Twenty 4 twenty: sustianable drainage. Accessed on 30 Sept 2016 at http:// www.thameswater.co.uk/about-us/19122.htm

Woods Ballard W, Wilson S, Udale-Clarke H, Illman S, Scott T, Ashley R, Kellagher R (2015) The SUDS Manual. CIRIA C697, London, 2015

Zhou Q (2014) A review of sustainable urban drainage systems considering the climate change and urbanization impacts. Water 6:976-992

Open Access This chapter is licensed under the terms of the Creative Commons Attribution 4.0 International License (http://creativecommons.org/licenses/by/4.0/), which permits use, sharing, adaptation, distribution and reproduction in any medium or format, as long as you give appropriate credit to the original author(s) and the source, provide a link to the Creative Commons license and indicate if changes were made.

The images or other third party material in this chapter are included in the chapter's Creative Commons license, unless indicated otherwise in a credit line to the material. If material is not included in the chapter's Creative Commons license and your intended use is not permitted by statutory regulation or exceeds the permitted use, you will need to obtain permission directly from the copyright holder.

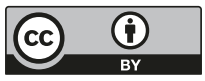

